\title{
Evaluation of the Genotoxicity and Cytotoxicity of Semipurified Fractions from the Mediterranean Brown Algae, Dictyopteris membranacea
}

\author{
Najoua Akremi, Davie Cappoen ${ }^{2}$, Roel Anthonissen ${ }^{1}$, Abderrahman Bouraoui, Luc Verschaeve ${ }^{1,3}$ \\ Faculté de Pharmacie, Université de Monastir, Monastir, Tunisia, 'Toxicology Unit, O.D. Food, Medicines and Consumer Safety, Scientific Institute of Public Health, J. \\ Wytsmanstraat 14, B-1050 Brussels, Belgium, ${ }^{2}$ Department of Pharmaceutical Sciences, University of Antwerp, Universiteitsplein 1, B-2610 Wilrijk, Belgium, ${ }^{3}$ Department \\ of Biomedical Sciences, University of Antwerp, Universiteitsplein 1, B-2610 Wilrijk, Belgium
}

\begin{abstract}
Dictyopteris membranacea, a species of Mediterranean brown algae, is believed to have potential pharmacological and nutritional applications. However, such potentials only make sense when devoid of any adverse health consequences. The present study should be seen in this context. It aimed at evaluating the genotoxicity and cytoxicity of its organic extract $\left(F_{0}\right)$ and semi purified fractions $\left(F_{4} F_{5}\right.$, and $\left.F_{6}\right)$. Extracts were tested using the bacterial Vitotox ${ }^{\circledast}$ test and micronucleus assay in different concentrations (from $1.25 \mu \mathrm{g} / \mathrm{mL}$ up to $100 \mu \mathrm{g} / \mathrm{mL}$, depending on the test and the extract). Applied concentrations were based on a preliminary dose-finding test with the neutral red uptake assay. The results show that all extracts were not genotoxic in the presence or absence of a rat metabolic enzyme fraction (S9). This is encouraging and justifies further investigations on the therapeutic and other values of this algae.
\end{abstract}

Key words: Cytotoxicity, Dictyopteris membranacea, genotoxicity, micronucleus, test, Vitotox test

\section{SUMMARY}

- Dictyopteris membranacea extracts and some of their semi purified fractions have important antibacterial properties.

- The organic extract $\left(F_{0}\right)$ and semi purified fractions $\left(F_{4^{\prime}} F_{5^{\prime}}\right.$ and $\left.F_{6}\right)$ were not genotoxic according to the bacterial Vitotox test.

- They were also not genotoxic according to the micronucleus test in human C3A cells.

- Applied concentrations were based on the in-vitro neutral red uptake (NRU) test.

\section{Correspondence:}

Najoua Akremi,

Faculté de Pharmacie de Monastir,

Rue Ibn Sina,

Monastir, Tunisie

E-mail: najoua.akremi@gmail.com

DOI : 10.4103/0973-1296.188318
Extracts and 3 semi-purified fractions

In vitro toxicity (NRU test) - dose finding Bacterial VITOTOX ${ }^{\circledR}$ assay Micronucleus test in C3A cells

$\checkmark$

No genotoxicity in the presence and absence of $\$ 9$

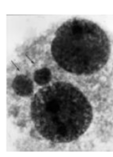

Access this article online Website: www.phcog.com

Quick Response Code:

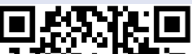
Fitring

\section{INTRODUCTION}

The oceans of the world occupy two-thirds of the planet's surface and provide a rich source of natural products. Marine macroalgae or seaweeds make up a large fraction of these natural products. Farmed or foraged from the wild, seaweeds are used for different purposes, including their application in traditional medicine. Several studies have shown interesting pharmacological and nutritional applications of seaweeds ${ }^{[1-5]}$ and therapeutic properties of bioactive metabolites isolated from algae. ${ }^{[6,7]}$ For this reason, new compounds are continuously isolated from marine resources and are investigated to unravel their biological properties. ${ }^{[8]}$ Brown algae (Phaeophyceae) are potential sources of ingredients with nutritional and/or therapeutic properties. They are already known to contain relatively more antioxidants than green and red algae, ${ }^{[9-12]}$ and their extracts also show higher antibacterial activities. ${ }^{[13]}$ Dictyopteris membranacea, a species of Mediterranean brown algae collected from the Tunisian coast, is furthermore well-known for its exceptional odoriferous capacity and is

currently being investigated for its potential therapeutic use. Its usage in the development of a new therapeutic means can, however, only be envisaged provided it is devoid of harmful effects. The aim of this study is, therefore, to investigate the genotoxicity of the organic extract and its semipurified fractions of Dictyopteris membranacea. This is important as genotoxic agents may, among others, induce hereditary diseases or cancer. Natural compounds that may be envisaged to

This is an open access article distributed under the terms of the Creative Commons Attribution-Non Commercial-Share Alike 3.0 License, which allows others to remix tweak, and build upon the work non-commercially, as long as the author is credited and the new creations are licensed under the identical terms.

For reprints contact: reprints @medknow.com

Cite this article as: Akremi N, Cappoen D, Anthonissen R, Bouraoui A, Verschaeve L. Evaluation of the genotoxicity and cytotoxicity of semipurified fractions from the Mediterranean brown algae, Dictyopteris membranacea. Phcog Mag 2016;12:395-9. 
become ingredients of food additives or health care products should, therefore, be devoid of any genotoxic properties.

\section{MATERIALS AND METHODS}

\section{Sample collection and preparation of the organic extract}

Dictyopteris membranacea plants were collected in June (summer) from the Mediterranean Sea in various areas of the coastal region of Monastir (Tunisia) at a depth between $2 \mathrm{~m}$ and $5 \mathrm{~m}$. The collected samples were rinsed with seawater and distilled water and then transported in cool boxes to the laboratory. The cleaned material was air dried to dryness in the shade at $30^{\circ} \mathrm{C}$. Finally, the dried samples were powdered and stored at $-20^{\circ} \mathrm{C}$ until use. Identification of specimens was carried out in the National Institute of Marine Sciences and Technologies (Salamboo,Tunisia).The organic extract of Dictyopteris membranacea was prepared by maceration of finely powdered material packed in small bags $(5 \mathrm{~cm} \times 10 \mathrm{~cm})$ of Whatman filter paper no. 1 with methanol and dichloro methane. This was done three times with intervals of 48 hours. The organic extract was concentrated to solvent free by evaporation in a rotating evaporator (Buchi, B-480) at $40^{\circ} \mathrm{C}$ and then stored at $-20^{\circ} \mathrm{C}$ until use.

\section{Purification of the organic extract}

Extracts of Dictyopteris membranacea were purified using C18 cartridges (Sep-pack, Supelco), by gradient elution with acetonitrile, acetone, and dichloromethane-methanol to give three semi purified fractions (respectively, $\mathrm{F}_{4}, \mathrm{~F}_{5}$, and $\mathrm{F}_{6}$ ). The solvents were removed from the fractions using rotating evaporator at $35^{\circ} \mathrm{C}$. The fractions were stored at $-20^{\circ} \mathrm{C}$ until use. The organic extract $\left(\mathrm{F}_{0}\right)$ and the fractions $\mathrm{F}_{4}, \mathrm{~F}_{5}$, and $\mathrm{F}_{6}$ were diluted to the desired final concentration immediately prior to manipulation.

\section{The neutral red uptake (nru) assay}

The NRU test measures cell viability based on the property of living cells to be able to take up neutral red dye into their lysosomes. ${ }^{[14]}$ Dying cells have altered membrane properties preventing them to take up neutral red (NR). The dye is applied to the cells and the $\mathrm{NI}_{50}$ concentration (50\% reduction of uptake) is determined by measuring $\mathrm{OD}_{540}$. This test was performed according to well-known standard methods. Human C3A cells were plated in 96 well plates ( 40.000 cells per well) and incubated in Dulbecco's Modified Eagle Medium (DMEM) + 10\% Fetal Bovine Serum (FBS) for 24 hours at $37^{\circ} \mathrm{C}$ and $5 \% \mathrm{CO}_{2}$. Next, extracts were added in different concentrations for another 24 hours. Cells were then washed with phosphate buffer saline (PBS) after which $200 \mu \mathrm{l} 0.05 \mathrm{mg} / \mathrm{mL}$ neutral red solution was added. After 3 hours, cells were again washed in PBS to remove the remaining dye. Addition of $200 \mu \mathrm{L}$ ethanol/acetic acid $(50 / 1)$ resulted in the release of the dye from the cells that were placed on a stirring plate until a homogenous color was formed (approximately 1 hour). The optical density (OD) was measured with a spectrophotometer. The $\mathrm{OD}_{620}$ measured as a reference value was subtracted from the $\mathrm{OD}_{540}$ which is the optical density at the wavelength at which maximal absorption of NR occurs. Absorption of non treated cells was given a $100 \%$ value to which data from exposed cells were compared. Sodium Dodecyl Sulfate (SDS) in concentrations of $0.42,0.35,0.28,0.21,0.14$, and $0.07 \mathrm{mM}$ was used as a positive control.

\section{Genotoxicity and cytotoxicity assays}

The organic extract and fractions were tested using the Vitotox ${ }^{\oplus}$ test which is a genotoxicity test based on SOS-induction. ${ }^{[15]}$ It gives information on both genotoxicity and toxicity of a sample. A detailed description of the Vitotox ${ }^{\oplus}$ test is given elsewhere. ${ }^{[15-17]}$ In summary, this test employs two different constructs of Salmonella typhymurium TA 104. One has a luciferase gene under the control of a modified recN promoter, which leads to light production when DNA is damaged (TA 104-recN2-4 strain or Genox strain), whereas the second one contains lux-genes under the control of a constitutive promoter so that the light production is not influenced by genotoxic compounds (pr1 or Cytox strain). It serves as an internal control wherein if the light production goes up, the test compounds affect the lux gene in a different way than by damaging the DNA. Furthermore, a decrease in light production would indicate a toxic response.

Light measurements were performed in a luminometer (Modulus Microplate Multimode Reader from Turner Biosystems) at $30^{\circ} \mathrm{C}$ every 5 minutes in each well during a 4-hour period after addition of the extract or fractions to the bacteria. Concentrations used were based on preliminary dose-finding and toxicity tests using the NRU assay. The extracts were dissolved in dimethyl sulfoxide to give a stock solution of $1 \mathrm{mg} / \mathrm{mL}$, and serial two fold dilutions were made resulting in a tested concentration range from $100 \mu \mathrm{g} / \mathrm{mL}$ to $1.25 \mu \mathrm{g} / \mathrm{mL}$. The samples were tested with and without the presence of a rat metabolic enzyme fraction (S9). 4 -Nitroquinoline oxide (4-NQO, 4ppb) was used as a positive control without $\mathrm{S} 9$ metabolic activation, whereas benzopyrene (Bap, 8ppm) was used as the positive control requiring $\mathrm{S} 9$ metabolic activation.

The signal to noise ratio $(\mathrm{S} / \mathrm{N})$ or, specifically, the light production of exposed bacteria divided by the light production of nonexposed bacteria is automatically calculated for each measurement. $\mathrm{S} / \mathrm{N}$ is calculated for both strains separately and the ratio between the maximum $\mathrm{S} / \mathrm{N}$ values of the exposed over the control strain.

A substance is considered genotoxic when:

- $\quad \max \mathrm{S} / \mathrm{N}($ genox) $/ \max \mathrm{S} / \mathrm{N}$ (cytox) $>1.5$

- $\max \mathrm{S} / \mathrm{N}$ in genox shows a good dose-effect relationship

- $\max \mathrm{S} / \mathrm{N}$ (genox/cytox) shows a good dose-effect relationship

A substance is considered cytotoxic when $\mathrm{S} / \mathrm{N}$ in the cytox strain decreases and becomes considerably lower than 0.8 .

\section{The micronucleus assay}

The micronucleus test ${ }^{[18]}$ was conducted in human C3A cells that were cultivated as described above, exposed to the test material after 24 hours, and then treated 24 hours later with $4.5 \mu \mathrm{g} / \mathrm{mL}$ cytocholasin B to block the cells in telophase, so as to be sure that cells were divided and, hence, may show induced micronuclei. Fixation occurred after a total cultivation time of 72 hours. Slides were then stained with DAPI (4,6-diamidino2-phenylindole) and analyzed with a Zeiss Axio Plan fluorescence microscope. Approximately 2000 binucleated cells were scored for the presence of micronuclei. MMS (methyl methane sulfonate; $15 \mu \mathrm{g} / \mathrm{mL}$ ) was used as a positive control. Samples were tested in concentrations that were based on the results of the neutral red uptake test, but cytotoxicity was also determined using the Cytokinesis-Block Proliferation Index (CBPI) which is calculated as the number of mononucleated cells $+2 x$ number of binucleated cells $+3 x$ number of multinucleated cells divided by the total number of cells. The CBPI was determined after examination of 500 acridine orange stained slides. Cytotoxicity is then calculated as:

Cytotoxicity $(=$ cytostasis $)=100-100\left\{\left(\mathrm{CBPI}_{\mathrm{T}}-1\right) /\left(\mathrm{CBPI}_{\mathrm{C}}-1\right)\right.$, where $\mathrm{CBPI}_{\mathrm{T}}$ is the CBPI of the test compound (extract or fraction) and $\mathrm{CBPI}_{\mathrm{C}}$ the CBPI of the unexposed control cells. This cytotoxicity evaluation usually goes along with the micronucleus test using cytochalasin B. It helps in determining appropriate test concentrations for the in vitro micronucleus $(\mathrm{MN})$ test. ${ }^{[19]}$

The highest concentration used should aim to achieve $55 \pm 5 \%$ cytotoxicity and, i.e. show a reduction in CBPI up to $45 \pm 5 \%$ of the concurrent negative control. ${ }^{[20]}$ 


\section{Statistical analysis}

No statistics are needed for the NRU test where we only determined $\mathrm{NI}_{50}$ values. The same holds true for the Vitotox ${ }^{\otimes}$ test where a dose-effect relationship and $\mathrm{S} / \mathrm{N}$ ratio (genox over cytox strain) reaching levels over 1.5 and requirements as outlined before are sufficient to decide about the presence or absence of genotoxicity. The Kastenbaum and Bowman ${ }^{[21]}$ tables were used for determining statistically significant deviations from (unexposed) controls. This binomial test was found adequate for the purpose of the present investigation. Here, the frequency of cells with micronuclei was compared between exposed cells and their unexposed controls. This means that we compared each test concentration with its negative control only. At this point, we did not take multiple comparisons into account.

\section{RESULTS AND DISCUSSION}

In this paper, we report on the in vitro cytotoxicity and genotoxicity of organic extracts of Dictyopteris membranacea which is at present extensively investigated with regard to their potential beneficial properties. The laboratory at the Faculty of Pharmacy (University of Monastir) is for example involved in studies on their antimicrobial and antitubercular activity. From such studies we already know that fractions $\mathrm{F}_{4}$ (acetonitrile) and $\mathrm{F}_{5}$ (acetone), especially, have important antibacterial properties (unpublished results).

The neutral red uptake and micronucleus tests were conducted in C3A cells because these cells largely conserved both phase I and phase II metabolic capacities. ${ }^{[22]}$ Tests can, therefore, be conducted in the absence of S9.

The results of the neutral red uptake test are summarized in Table 1 where $\mathrm{NI}_{50}$ concentrations are given. $\mathrm{F}_{4}$ presents the lowest concentration of $\mathrm{NI}_{50}$ and the highest concentration is for the organic extract $\left(\mathrm{F}_{0}\right)$. Concentrations tested were based on the results of the NRU test. Cytotoxicity determination based on CBPI showed that all concentrations were accurate as the maximum percent cytostasis fluctuated between $32.71 \%\left(\mathrm{~F}_{0}\right)$ and $52.04 \%\left(\mathrm{~F}_{6}\right)$ (see Table 2).
Table 1: Concentrations of $50 \%$ reduction of neutral red uptake $\left(\mathrm{NI}_{50}\right)$ for the organic extract and the fractions $\mathrm{F}_{4^{\prime}} \mathrm{F}_{5^{\prime}}$ and $\mathrm{F}_{6}$

\begin{tabular}{lcc}
\hline Fraction & Solvent & $\mathrm{NI}_{50}(\mu \mathrm{g} / \mathrm{ml})$ \\
\hline Methanolic extract $\mathrm{F}_{0}$ & Methanol & 142.5 \\
$\mathrm{~F}_{4}$ & Acetonitrile & 21.16 \\
$\mathrm{~F}_{5}$ & Acetone & 51.2 \\
$\mathrm{~F}_{6}$ & Dichloromethane- & 83.1 \\
& methanol (1:1) & \\
\hline
\end{tabular}

The Vitotox ${ }^{\oplus}$ test is a test for bacterial genotoxicity based on SOS induction. Its results correlate well with the Ames assay. ${ }^{[15,23,24]}$ The Vitotox ${ }^{\circledast}$ test was found very suitable and highly efficient for (high throughput) screening of chemicals to determine their genotoxic potential. ${ }^{[16,17]}$ It was also shown to be particularly useful in the research or prescreening phase in the pharmaceutical industry. ${ }^{[23,25]}$ The test is usually more sensitive than the Ames assay as it detects lower concentrations of a genotoxic compound. ${ }^{[15-17]}$ It also requires only limited amounts of a test compound. This is one of the major advantages of the test for prescreening purposes where usually only small amounts of the test compound are available (e.g., in the discovery phase of a new pharmaceutical agent).

As expected, the positive control 4-NQO was found to be genotoxic as light production was induced over an $\mathrm{S} / \mathrm{N}$ of 1.5 , and no cytotoxicity $(\mathrm{S} / \mathrm{N} \sim 1$ ) was found. Benzo( $\alpha$ )pyrene also showed genotoxicity without being cytotoxic in the presence of metabolic activation. This can be seen in Figures 1 and 2. These figures also show that the organic extract $\mathrm{F}_{0}$ and the fractions $\mathrm{F}_{4}, \mathrm{~F}_{5}$, and $\mathrm{F}_{6}$ were not genotoxic in the presence and absence of $\mathrm{S} 9(\mathrm{~S} / \mathrm{N}<1.5)$. Cytotoxicity was, however, found at the higher doses. Without addition of S9, cytotoxicity was obvious $(\mathrm{S} / \mathrm{N}$ in the cytox strain well below 0.8 ) for the organic extract at $>50 \mu \mathrm{g} / \mathrm{mL}$, and respectively at $>50,>5$, and $>25 \mu \mathrm{g} / \mathrm{mL}$ for $\mathrm{F}_{4}, \mathrm{~F}_{5}$, and $\mathrm{F}_{6}$. Cytotoxicity was also obvious in the presence of $S 9$ and found at $>50,>25,>100$, and $>25$ $\mathrm{mg} / \mathrm{mL}$ for the organic extract $\mathrm{F}_{4}, \mathrm{~F}_{5}$, and $\mathrm{F}_{6}$, respectively.

Table 2: Micronucleus test applied to the organic extract $F_{0}$ and its fractions $F_{4^{\prime}} F_{5^{\prime}}$ and $F_{6}$.

\begin{tabular}{|c|c|c|c|c|c|c|}
\hline & Number of MN & $\begin{array}{l}\text { Number of BN } \\
\text { cells }\end{array}$ & MN/2000 cells & CBPI & CBPI (\% of control) & Cytostasis \\
\hline Unexposed control & 32 & 2663 & 24.0 & 1.538 & - & - \\
\hline MMS $(15 \mu \mathrm{g} / \mathrm{ml})$ & 68 & 1940 & $70.1(P<0.05)$ & 1.582 & 102.83 & -8.18 \\
\hline $\mathrm{F}_{0}(12.5 \mu \mathrm{g} / \mathrm{ml})$ & 19 & 17,6 & 22.3 & 1.586 & 103.09 & -8.92 \\
\hline $\mathrm{F}_{0}(25 \mu \mathrm{g} / \mathrm{ml})$ & 19 & 1933 & 19.7 & 1.482 & 96.33 & 10.41 \\
\hline $\mathrm{F}_{0}(50 \mu \mathrm{g} / \mathrm{ml})$ & 9 & 2012 & 8.9 & 1.524 & 99.09 & 2.60 \\
\hline $\mathrm{F}_{0}(100 \mu \mathrm{g} / \mathrm{ml})$ & 15 & 1314 & 22.8 & 1.362 & 88.56 & 32.71 \\
\hline $\mathrm{F}_{4}(2.5 \mu \mathrm{g} / \mathrm{ml})$ & 26 & 2041 & 25.5 & 1.52 & 98.8 & 3.35 \\
\hline $\mathrm{F}_{4}(5 \mu \mathrm{g} / \mathrm{ml})$ & 25 & 2036 & 24.6 & 1.526 & 99.32 & 2.23 \\
\hline $\mathrm{F}_{4}(10 \mu \mathrm{g} / \mathrm{ml})$ & 25 & 1929 & 25.9 & 1.514 & 98.41 & 4.46 \\
\hline $\mathrm{F}_{4}(15 \mu / \mathrm{ml})$ & 6 & 987 & 12.2 & 1.322 & 85.93 & 40.15 \\
\hline $\mathrm{F}_{5}(3.125 \mu \mathrm{g} / \mathrm{ml})$ & 29 & 2271 & 25.5 & 1.546 & 100.49 & -1.49 \\
\hline $\mathrm{F}_{5}(6.25 \mu \mathrm{g} / \mathrm{ml})$ & 21 & 1466 & 28.6 & 1.512 & 98.28 & 4.83 \\
\hline $\mathrm{F}_{5}(12.5 \mu \mathrm{g} / \mathrm{ml})$ & 13 & 2159 & 12 & 1.554 & 101.01 & -2.97 \\
\hline $\mathrm{F}_{5}(25 \mu \mathrm{g} / \mathrm{ml})$ & 13 & 1083 & 24 & 1.292 & 83.98 & 45.72 \\
\hline $\mathrm{F}_{6}(6.125 \mu \mathrm{g} / \mathrm{ml})$ & 28 & 3313 & 25.3 & 1.556 & 110.36 & -3.35 \\
\hline $\mathrm{F}_{6}(12.5 \mu \mathrm{g} / \mathrm{ml})$ & 17 & 2132 & 15.9 & 1.544 & 101.14 & -1.11 \\
\hline $\mathrm{F}_{6}(25 \mu \mathrm{g} / \mathrm{ml})$ & 22 & 2138 & 20.6 & 1.458 & 94.77 & 14.87 \\
\hline $\mathrm{F}_{6}(50 \mu \mathrm{g} / \mathrm{ml})$ & 11 & 1456 & 15.1 & 1.258 & 83.59 & 52.04 \\
\hline
\end{tabular}




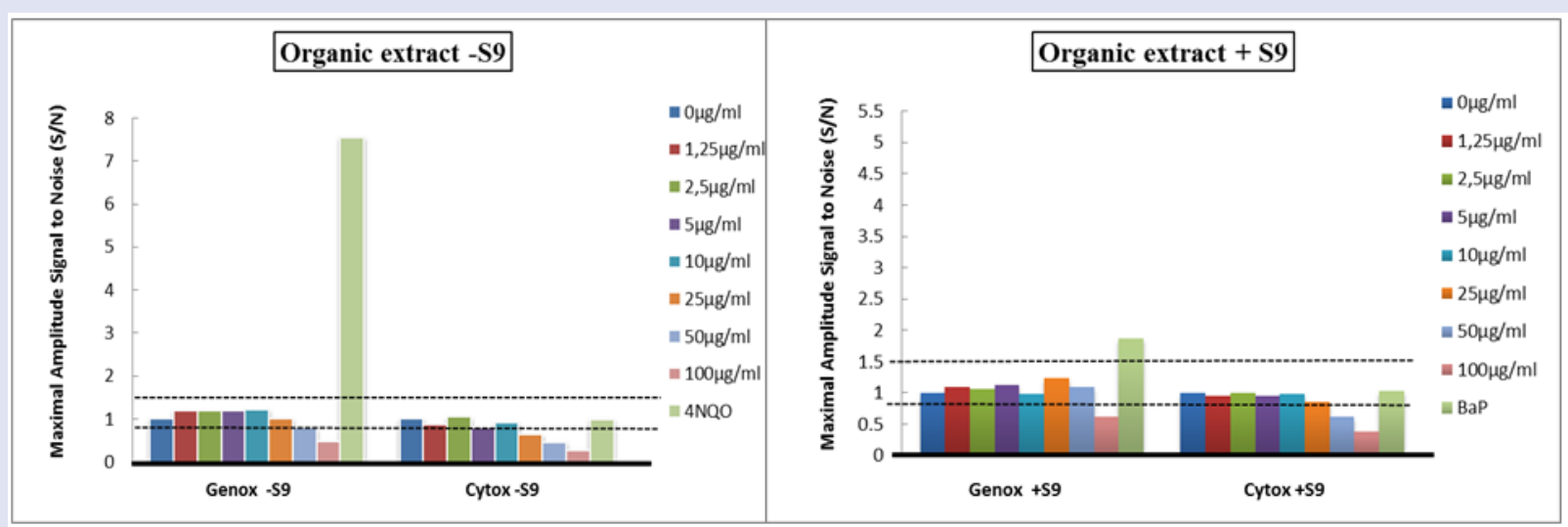

Figure 1: VITOTOX ${ }^{\circledast}$ test results for the organic extract $\mathrm{F}_{0}$ in the absence and presence of S9. The horizontal line at $\mathrm{S} / \mathrm{N}=1.5$ indicates the threshold level for genotoxicity in the Genox strain, whereas the line at $\mathrm{S} / \mathrm{N}=0.8$ gives the level below which $\mathrm{S} / \mathrm{N}$ is indicative of a toxic response in the Cytox strain. 4-NQO and Bap = positive control.

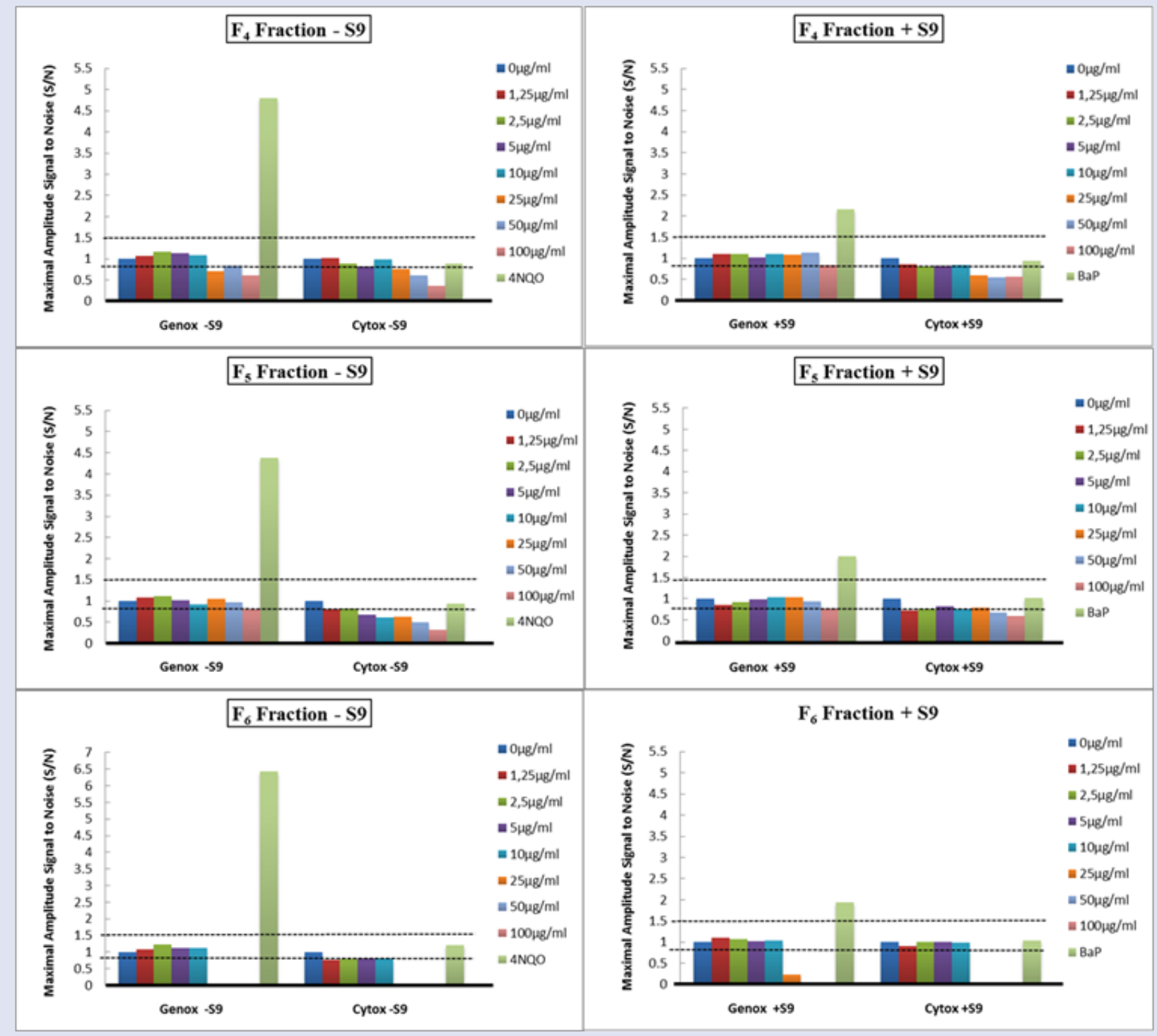

Figure 2: VITOTOX ${ }^{\oplus}$ test results for the fractions $\mathrm{F}_{4^{\prime}} \mathrm{F}_{5^{\prime}}$ and $\mathrm{F}_{6}$ in the absence and presence of $\mathrm{S} 9$ (see also legend of Figure 1 for details). 
Bacterial cytotoxicity in the Vitotox ${ }^{\oplus}$ test strain was, thus, not totally in agreement with the results from the NRU test and CBPI/cytostasis determinations. This is not surprising as the different assays measure cytotoxicity based on totally different endpoints. It should also be noted that we often found a cytotoxic (or cytotoxic-like) response with the Vitotox $^{\infty}$ test when complex mixtures were studied. This already occurred at concentrations that were non-toxic or subtoxic according to the NRU test or at concentrations that did not affect the growth of Umu-C Salmonella typhimurium (TA 1535) bacteria. ${ }^{[16,17,26]}$ This is probably due to an interaction of the sample or some of its constituents with the metabolic pathways in which the luciferase operon is involved. ${ }^{[17]}$ This can at first sight be seen as a disadvantage of the Vitotox ${ }^{\oplus}$ test. We, however, previously demonstrated that this test can perfectly be used for such samples (extracts) and be valuable for the (pre)screening of large numbers of samples, including, for example, extracts from plants. ${ }^{[27]}$ It should be noted that the Vitotox ${ }^{\circ}$ test often enables genotoxicity testing at much lower concentrations than other test systems and that Vitotox ${ }^{\oplus}$ results are, therefore, often valid even when only low(er) concentrations could be tested. ${ }^{[28]}$ The Vitotox $^{\oplus}$ test, hence, remains valuable as a first screening test.For this reason, the test was applied to our extract and semi purified fractions. However, this test is only a rapid indicator test for DNA damage which means that further mutation tests in mammalian/human cells may be necessary yet. We, therefore, also conducted the micronucleus assay which is now recognized as one of the most successful and reliable assays for genotoxic carcinogens. A micronucleus is formed during the metaphase/anaphase transition of mitosis (cell division). It may arise from a whole lagging chromosome (aneugenic event leading to chromosome loss) or an acentric chromosome fragment detaching from a chromosome after breakage (clastogenic event) which does not integrate in the daughter nuclei. Scoring of micronuclei in telophase cells is, therefore, a convenient way to investigate the potential of an agent to induce structural and numerical chromosome aberrations. Together with the Vitotox ${ }^{\circledR}$ test, we cover gene mutations (which the Vitotox ${ }^{\oplus}$ test detects due to its high concordance with the Ames assay) and structural and numerical chromosome mutations.

The results of the micronucleus test are given in Table 2. It can be seen that only the positive control $(15 \mu \mathrm{g} / \mathrm{mL}$ MMS $)$ induced micronuclei in a statistically significant way. The organic extract $\left(\mathrm{F}_{0}\right)$ and its semi purified fractions $\left(\mathrm{F}_{4}, \mathrm{~F}_{5}\right.$, and $\left.\mathrm{F}_{6}\right)$ from the Mediterranean brown algae, Dictyopteris membranacea, were shown not to significantly induce micronuclei in the C3A cells.

In conclusion, according to our results, the organic extract and the $\mathrm{F}_{4}, \mathrm{~F}_{5}$, and $\mathrm{F}_{6}$ fractions are not genotoxic. To the best of our knowledge, this is the first report on the evaluation of the genotoxic and cytotoxic effects of the tested algae extract or fractions. It shows that they can (so far) be considered safe in terms of their potential in vitro genotoxic properties. This is encouraging with respect to further investigations on their therapeutic value.

\section{Financial support and sponsorship}

Nil

\section{Conflicts of interest}

There are no conflicts of interest

\section{REFERENCES}

1. Cardozo KHM, Guaratini T, Barros MP, Falcao VR, Tonon AP, Lopes NP, et al. Metabolites from algae with economical impact. Comparative Biochemistry and Physiology - Part C: Toxicology Pharmacology 2007; 146:60-78.

2. Chu WL. Potential applications of antioxidant compounds derived from algae. Current Topics in Nutraceutical Research 2011; 9:83-98.
3. Lordan S, Ross RP, Stanton C. Marine bioactives as functional food ingredients: potential to reduce the incidence of chronic diseases. Marine Drugs 2011; 9:1056-100.

4. Smit AJ. Medicinal and pharmaceutical uses of seaweed natural products: a review. Journal of Applied Phycology 2004; 16:245-62.

5. Thomas NN, Kim SK. Potential pharmacological applications of polyphenolic derivatives from marine brown algae. Environmental Toxicology and Pharmacology 2011; 32:325-35.

6. Fisch KM, Böhm V, Wright AD, König GM. Antioxidative meroterpenoids from the brown alga Cystoseira Crinita. Journal of Natural Products 2003; 66:968-75

7. PuntipW, Masayuk K. Bioactive phloroglucinols from the brown alga Zonaria diesingiana. Journal of Applied Phycology 2003; 15:22-58.

8. Blunt JW, Copp BR, Keyzers RA, Munro MHG, Prinsep MR. Marine natural products. Natural Product Reports 2012; 29:144-222

9. Al-Amoudi OA, Mutawie HH, Patel AV, Blunden G. Chemical composition and antioxidant activities of Jeddah corniche algae. Saudi Journal of Biological Sciences 2009; 16:23-9.

10. Costa LS, Fidelis GP, Cordeiro SL, Oliveira RM, Sabry DA, Camara RBG, et al. Biological activities of sulfated polysaccharides from tropical seaweeds. Biomedicine and Pharmacotherapy 2010; 64:21-8.

11. Cox S, Abu-Ghannam N, Gupta S. An assessment of the antioxidant and antimicrobial activity of six species of edible Irish seaweeds. International Food Research Journal 2010; 17:205-20.

12. Batista Gonzalez AE, Charles MB, Mancini-Filho J, Vidal Novoa A. Seaweeds as sources of antioxidant phytomedicines. Revista Cubana de Plantas Medicinales 2009; 14:1-18.

13. Valchos V, Critchley AT, Von Holy A. Antimicrobial activity of extracts from selected Southern African marine macroalgae. South African Journal of Science 1997; 93:328-32.

14. RepettoG, Del Peso A, Zurita JL. Neutral red uptake assay for the estimation of cell viability/ cytotoxicity. Nature Protocols 2008; 3:1125-31.

15. Verschaeve L, Van Gompel J, Regniers L, Van ParijsPh, Van der Lelie D. VITOTOX®genotoxicity and toxicity test for the rapid screening of chemicals. Environmental and Molecular Mutagenesis 1999;33:240-8.

16. Verschaeve L. The VITOTOX ${ }^{\circledR}$ genotoxicity test. In: Pandali SG, editor. Recent research developments in applied microbiology and biotechnology. Trivandrum. Research Signpost 2005; 33-49.

17. Verschaeve L. High-throughput bacterial mutagenicity testing: Vitotox ${ }^{\mathrm{TM}}$ assay. In: Steinberg P, editor.High throughput screening methods in toxicity testing. Hoboken: Wiley Publications 2013; 213-32.

18. Fenech M. The in vitro micronucleus technique. Mutation Research 2000; 455:81-95.

19. Lorge E, Hayashi M, Albertini S, Kirkland D. Comparison of different methods for an accurate assessment of cytotoxicity in the in vitro micronucleus testl. Theoretical aspects. Mutation Research 2008; 655:1-3.

20. OECD guideline for the testing of chemicals: in vitro mammalian cell micronucleus test. Technical guideline Nr 2014;487:87.

21. Kastenbaum MA, Bowman KO. Tables for determining the statistical significance of mutation frequencies. Mutation Research 1970; 9:527-49.

22. Kelly JH. Permanent human hepatocyte cell line and its use in a liver assist device (LAD). US Patent Number 1994; 5:290-68.

23. Muto S, Miyata K, Tsutsumibata C, Daigo H, OoroT, Sugiura K, et al. A practical application of the VITOTOX'M test for genotoxicity screening. In: Verschaeve L, editor. Topical issues in applied microbiology and biotechnology. Trivandrum. Research Signpost 2006; 1-9.

24. Westerink WMA, Stevenson JCR, Lauwers A, Griffioen G, Horbach CJ, Schoonen WGEJ, et al. Evaluation of the Vitotox ${ }^{\mathrm{TM}}$ and RadarScreen assays for the rapid assessment of genotoxicity in the early research phase of drug development. Mutation Research 2009;676:113-30.

25. Muto S, Baba H, Uno Y. Evaluation of the VITOTOX'M test as a high-throughput genotoxicity assay. Environment Mutagenesis Research 2003; 25:69-75.

26. Brits $E$, Regniers $L$. Verschaeve $L$, Bacterial genotoxiciy tests; umu-C and VITOTOX ${ }^{\circledR}$ test: a comparison with Salmonella mutagenicity. In: Verschaeve L, editor. Topical issues in applied microbiology and biotechnology. Kerala. Research Signpost 2006: 11-21.

27. Verschaeve L, Van Staden J. Mutagenic and antimutagenic properties of extracts from South African traditional medicinal plants. Journal of Ethnopharmacology 2008; 119: 575-87.

28. Verschaeve L, Maes J, Ligh M, Van Staden J. Genetic toxicity testing of 3-methyl-2Hfuro[2,3-c]pyran-2-one, an important biologically active compound from plant-derived smoke. Mutation Research 2006; 611:89-95. 